\title{
ANALISIS PENERIMAAN PAJAK KENDARAAN BERMOTOR (PKB) DI KOTA PALU
}

\author{
Anggy Putra \\ Muh. Faisal \\ Cici Rianty K. Bidin \\ Jurusan Manajemen, Fakultas Ekonomi, Universitas Tadulako \\ Email: anggydisturber@gmail.com
}

\begin{abstract}
This study determines the growth, effectiveness, efficiency, and contribution of motor vehicle tax revenue in Palu City. Based on the results for over 5 years from 2011 to 2015, the growth of taxes on motor vehicles increases annually but in percentage is fluctuated with $13.39 \%$ of achievement in average. This is due to the lack of public awareness and cooperation of government about the importance of the tax. However, the effectiveness of the motor vehicle tax in Palu is very effective with the average percentage of $109.17 \%$. This achievement is supported by good supervision and control towards the motor vehicle tax collection in Palu. The level of efficiency of the motor vehicle tax in Palu is categorized efficient. This is caused by the amount of collection only 5\%; the implementation of motor vehicle tax efficiency in Palu by the government especially by UPTD Palu and contribution rate of motor vehicle taxes in Palu show good growth.
\end{abstract}

Keywords: motor vehicle tax in palu

\section{ABSTRAK}

Penelitian ini bertujuan untuk mengetahui pertumbuhan, efektifitas, efisiensi, dan kontribusi penerimaan Pajak Kendaraan Bermotor di Kota Palu. Lokasi Penelitian ini adalah di kantor Dinas Pendapatan Daerah Kota Palu. Berdasarkan hasil penelitian selama 5 tahun yaitu dari tahun 2011 2015, bahwa pertumbuhan pajak kendaraan bermotor setiap tahunnya secara rill terlihat meningkat namun secara persentase mengalami fluktuasi dengan pencapaian rata-rata sebesar 13,39\%. Hal ini dikarenakan oleh kurangnya kesadaran masyarakat dan kerja sama dari pemerintah terhadap pentingnya pajak itu sendiri. Meskipun demikian tingkat efektifitas pajak kendaraan bermotor Kota Palu menunjukkan pencapaian sangat efektif dengan persentase rata-rata sebesar 109,17\%. Hal ini didukung oleh adanya proses pengendalian dan pengawasan yang baik terhadap pemungutan pajak kendaraan bermotor di Kota Palu. Pada tingkat efisiensi pajak kendaraan bermotor di Kota Palu dikategorikan efisien. Hal ini disebabkan oleh besarnya biaya pungut yang ditetapkan hanya sebesar $5 \%$ serta implementasi efisiensi pajak kendaraan bermotor di Kota Palu yang telah di lakukan oleh pemerintah khususnya pihak UPTD Kota Palu mengalami perkembangan, dan untuk tingkat kontribusi pajak kendaraan bermotor Kota Palu mengalami pertumbuhan yang baik.

Kata Kunci: Pajak Kendaraan Bemotor di Kota Palu

\section{PENDAHULUAN}

Pembangunan nasional selalu berdampak pada pembangunan daerah. Secara hirarki ini merupakan suatu kegiatan yang berlangsung secara terus-menerus dan berkesinambungan yang bertujuan untuk meningkatkan kesejahteraan rakyat. Untuk mensukseskan pembangunan nasional, diperlukan adanya pembiayaan pembangunan baik yang berasal dari penerimaan pemerintah pusat maupun penerimaan pemerintah daerah.

Salah satu penerimaan daerah yang sangat penting bagi pelaksanaan dan pembangunan daerah serta bertujuan untuk meningkatkan kemakmuran dan kesejahteraan masyarakat adalah pajak. Sebagaimana yang telah diatur dalam Peraturan Daerah Provinsi Sulawesi Tengah Nomor 1 Tahun 2011 Tentang Pajak Daerah Pasal 1 ayat 6 yang berbunyi Pajak Daerah yang selanjutnya disebut pajak adalah kontribusi wajib kepada daerah yang terutang oleh orang pribadi atau badan yang bersifat memaksa berdasarkan Undang-Undang dengan tidak mendapatkan imbalan secara langsung dan digunakan untuk keperluan Daerah bagi sebesar-besarnya kemakmuran rakyat. 
Pajak merupakan alat bagi pemerintah dalam mencapai tujuan untuk mendapatkan penerimaan, baik yang bersifat langsung maupun tidak langsung dari masyarakat guna membiayai pengeluaran rutin serta pembangunan nasional dan ekonomi masyarakat. Berdasarkan kewenangannya, pajak dapat dibedakaan sebagai Pajak Pusat dan Pajak Daerah. Dengan dikeluarkannya Undang-Undang Nomor 34 Tahun 2000 tentang Perubahan atas Undang - Undang Republik Indonesia Nomor 18 Tahun 1997 tentang Pajak Daerah dan Retribusi Daerah, yang berisi Ketentuan-ketentuan pokok yang memberikan pedoman kebijakan dan arahan bagi daerah dalam pelaksanaan pemungutan pajak daerah dan retribusi daerah, sekaligus menetapkan pengaturan untuk menjamin penetapan prosedur umum perpajakan daerah dan retribusi daerah.

Pajak Kendaraan Bermotor (PKB) merupakan salah satu kontribusi dalam meningkatkan Pendapatan Asli Daerah (PAD) di Kota Palu. Berikut data realisasi penerimaan Pajak Kendaraan Bermotor (PKB) untuk tahun anggaran 2011 s/d 2015 dapat dilihat pada tabel di bawah ini:

Tabel 1 Target dan Realisasi Penerimaan Pajak Kendaraan Bermotor (PKB) di Kota Palu Tahun 2011-2015

\begin{tabular}{|c|c|c|c|}
\hline No. & Tahun & Target (Rp.) & Realisasi (Rp.) \\
\hline 1. & 2011 & $50.143 .345 .733,00$ & $55.695 .994 .014,00$ \\
\hline 2. & 2012 & $64.846 .430 .500,00$ & $66.004 .226 .184,00$ \\
\hline 3. & 2013 & $69.668 .943 .500,00$ & $75.218 .260 .771,00$ \\
\hline 4. & 2014 & $79.575 .801 .500,00$ & $78.231 .497 .488,00$ \\
\hline 5. & 2015 & $99.675 .677 .272,00$ & $91.595 .969 .893,00$ \\
\hline
\end{tabular}

Sumber data : Dinas Pendapatan Daerah Provinsi Sulawesi Tengah (April 2016)

Melihat Tabel di atas, target dan realisasi penerimaan Pajak Kendaraaan Bermotor (PKB) di kota Palu dari tahun 2011 sampai dengan tahun 2015 terlihat jelas perbedaan yang cukup signifikan. Pada tahun 2011 UPTD WIL. I PALU mengalami kenaikan penerimaan Pajak Kendaraan Bermotor (PKB) yang besar ini terlihat dari target 2011 sebesar Rp. 50.143.345.733,00 dan realisasi sebesar Rp. 55.695.994.014,00. Selain tahun 2011 tercapai, jumlah target dan realisasi juga tercapai di tahun 2012 dan 2013. Tetapi pada tahun 2014 dan 2015 target dan realisasi tidak berjalan dengan baik karena jumlah target pada tahun 2014 tidak tecapai. Begitu pula di tahun 2015 jumlah target tidak tercapai sama seperti tahun 2014.

Penerapan wajib pajak pada kendaraan bermotor, tentunya sangat berperan penting di dalam meningkatkan Pendapatan Asli Daerah (PAD), pembiayaan penyelenggaraan pemerintah daerah dan pembangunan ekonomi daerah serta kesejahteraan masyarakat. Dengan hasil penerimaan Pajak Kendaraan Bermotor (PKB) yang cukup besar tetapi pada 2 tahun terakhir jumlah target tidak tercapai, maka peneliti tertarik untuk meneteliti tujuan:

1. Untuk mengetahui Pertumbuhan Pajak Kendaraan Bermotor (PKB) di Kota Palu

2. Untuk mengetahui Tingkat Efektifitas Pajak Kendaraan Bermotor (PKB) di Kota Palu

3. Untuk mengetahui Tingkat Efisiensi Pajak Kendaraan Bermotor (PKB) di Kota Palu

4. Untuk mengetahui Kontribusi Pajak Kendaraan Bermotor (PKB) Di Kota Palu

\section{KAJIAN LITERATUR}

\section{Keuangan Daerah}

Pengelolaan Keuangan daerah menurut Halim (2007:330) adalah keseluruhan kegiatan yang meliputi, pelaksanaan, penatausahaan, pelaporan, pertanggungjawaban dan penguasaan keuangan daerah. Keuangan Daerah pada hakikatnya mengacu kepada landasan idiil: Pancasila, Landasan Konstitusional: Undang-Undang Dasar 1945. Wawasan Nusantara dan Ketahanan Nasional sebagai landasan konseptual, Garis-Garis Besar Haluan Negara (GBHN), Program Pembangunan Nasional 
(Propenas), Rencana Pembangunan Tahunan (Repeta), Pola Dasar (Poldas), program pembangunan daerah (Propeda), Rencana Pembangunan Tahunan Daerah (Repetada) dan Rencana Anggaran dan Pendapatan Dan Belanja Daerah (RAPBN).

\section{Pajak}

Menurut Mangkoesoebroto (1998) pajak adalah suatu pungutan yang merupakan hak preogratif pemerintah, pungutan tersebut didasarkan pada undang-undang, pemungutannya dapat dipaksakan kepada subyek pajak untuk mana tidak ada balas jasa yang langsung dapat ditunjukkan penggunaannya. Dari definisi tersebut, dapatdisimpulkan bahwa yang berhak memungut pajak adalah negara (pemerintah). Pajak adalah suatu cara negara untuk membiayai perekonomiannya sendiri dan pengeluaran lainnya secara umum disamping kewajiban suatu warga negara. Pajak juga merupakan partisipasi masyarakat yang dirasa paling efektif dalam proses pembangunan. Oleh karena itu, pajak dapat dijadikan alat sebagai penggerak partisipasi rakyat kepada negara.

\section{Fungsi Pajak}

Menurut Ilyas dan Burton (2001:8), terdapat empat fungsi pajak yaitu:

1. Fungsi Budgeter yaitu fungsi untuk mengumpulkan uang hasil pajak sebanyak-banyaknya sesuai dengan undang-undang yang berlaku pada waktunya akan digunakan untuk membiayai pengeluaran-pengeluaran Negara baik untuk pengeluaran rutin maupun untuk pembangunan.

2. Fungsi Regulerend yaitu pajak sebagai alat untuk mencapai tujuan-tujuan tertentu yang letaknya diluar bidang keuangan.

3. Fungsi Demokrasi yaitu suatu fungsi yang merupakan salah satu penjelmaan dan pembangunan demi kesejahteraan masyarakat.

4. Fungsi Distribusi yaitu fungsi yang lebih menekankan pada unsur pemerataan dan keadilan dalam masyarakat.

\section{Pembagian Jenis Pajak}

Beberapa jenis pajak dapat dilihat dari penggolongan pajak yang dibedakan menurut golongannya, sifatnya dan menurut lembaga pemungutnya.

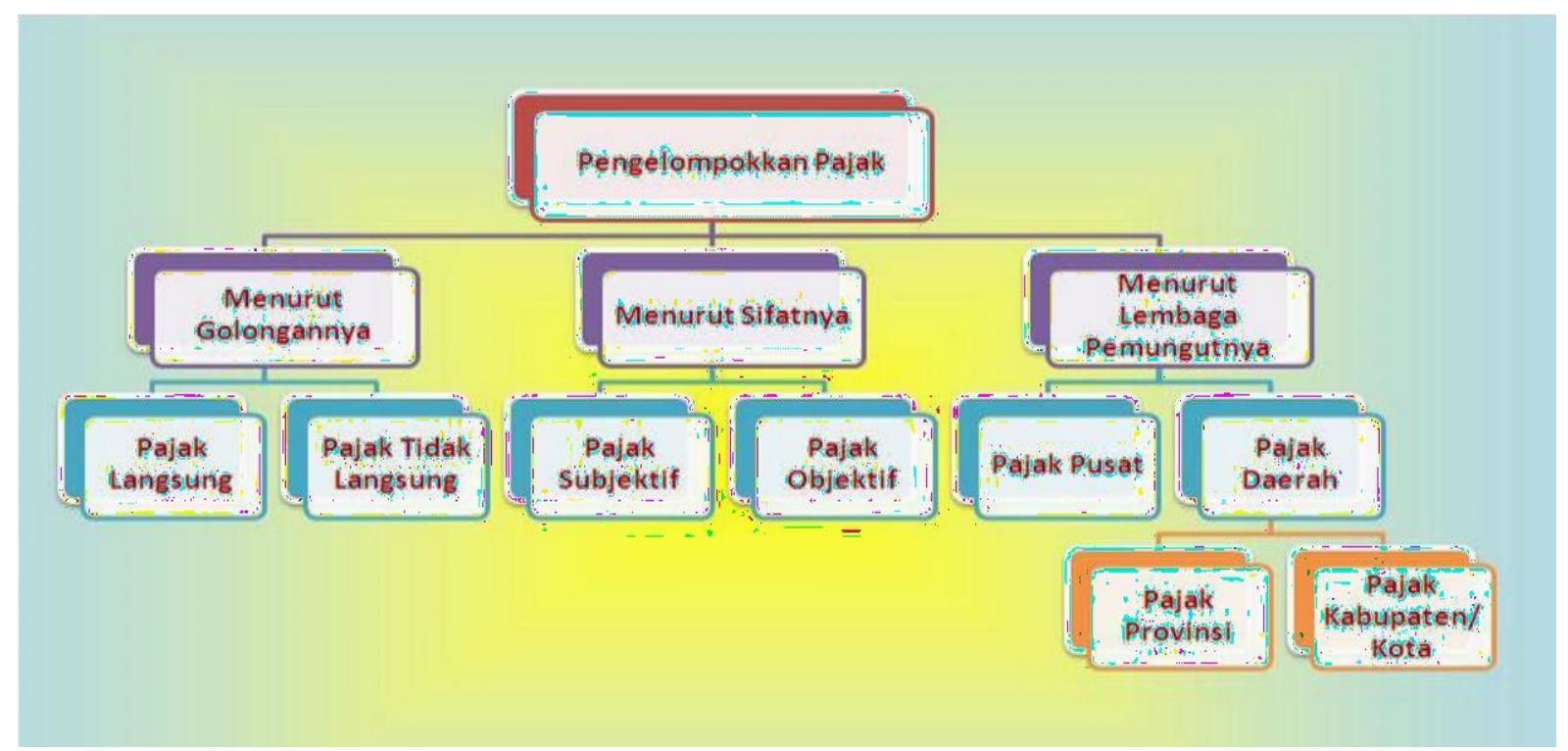

Sumber: http://catatansmaku.blogspot.com/2011/08/pengelompokan-pajak.html

\section{Gambar 1 Skema Pengelompokkan Pajak}


Putra A.

\section{Pajak Menurut Golongannya}

Menurut Golongannya Pajak dibagai menjadi dua, yaitu:

1. Pajak Langsung. Dalam pengertian ekonomi, pajak langsung adalah pajak yang bebannya harus dipikul sendiri oleh wajib pajak yang bersangkutan, tidak boleh dilimpahkan kepada orang lain

2. Pajak Tidak Langsung. Dalam pengertian ekonomis, pajak tidak langsung adalah pajak - pajak yang bebannya dapat dilimpahkan kepada pihak ketiga atau konsumen

\section{Pajak Menurut Sifatnya}

Menurut sifatnya, Pajak dibagi menjadi dua yaitu:

1. Pajak Subyektif (bersifat perorangan)

Pajak subyektif adalah pajak yang memperhatikan pertama-tama keadaan pribadi wajib pajak untuk menetapkan pajaknya harus ditemukan alasan-alasan yang obyektif yang berhubungan erat dengan keadaan materialnya, yaitu yang disebut gaya pikul.

2. Pajak Obyektif (bersifat kebendaan)

Pajak obyektif pertama -tama melihat kepada obyeknya baik itu berupa benda, dapat pula berupa keadaan, perbuatan atau peristiwa yang mengakibatkan timbulnyakewajiban membayar, kemudian barulah dicari subyeknya (orang atau badan hukum) yang bersangkutan langsung dengan tidak mempersoalkan apakah subyek pajak ini berdomisili di Indonesia atau tidak.

\section{Menurut Lembaga Pemungutannya}

Menurut Lembaga Pemungutannya, pajak dibagi menjadi dua yaitu:

a. Pajak Negara (pajak pusat)

Pajak Negara yang berlaku di Indonesia sampai saat ini adalah:

1. Pajak Pertambahan Nilai dan Pajak Penjualan atas Barang Mewah (PPN dan PPn BM).

2. Pajak Penghasilan (PPh)

3. Pajak Bumi dan Bangunan (PBB)

4. Bea Materai

5. Bea Perolehan Hak atas Tanah dan Bangunan (BPHTB)

b. Pajak Daerah

Pajak daerah merupakan pajak - pajak yang dipungut oleh Daerah Provinsi, Kabupaten / Kota, pemungutanya berdasarkan pada Peraturan Daerah masing - masing dan hasilnya digunakan untuk pembiayaan Rumah Tangga Daerah masing -masing. Dasar hukum pengenaan pajak daerah adalah Undang-Undang Nomor 28 Tahun 2009.

\section{Pajak Kendaraan Bermotor (PKB)}

Berdasarakan Undang-undang Nomor 34 tahun 2000 dan diperkuat dengan Peraturan Pemerintah Nomor 65 tahun 2001 tentang Pajak Daerah dikatakan Pajak Kendaraan Bermotor (PKB), adalah pajak yang dipungut atas kepemilikan atau penguasaan kendaran bermotor.

\section{Dasar Hukum Pajak Kendaraan Bermotor}

Dasar hukum pajak kendaraan bermotor diatur dalam :

1. Undang-Undang Nomor 34 tahun 2000 yang merupakan perubahan atas Undang-Undang Nomor 18 tahun 1997 tentang Pajak Daerah dan Retribusi Daerah.

2. Peraturan Pemerintah Nomor 65 tahun 2001 tentang Pajak Daerah.

3. Peraturan daerah provinsi yang mengatur tentang PKB. Peraturan daerah ini dapat menyatu, yaitu satu peraturan daerah untuk PKB, tetapi dapat juga dibuat secara terpisah misalnya Peraturan Daerah tentang PKB.

4. Peraturan Menteri Dalam Negeri Nomor 2 tahun 2006 tentang Perhitungan Dasar Pengenanan Pajak Kendaraan Bermotor dan Bea Balik Nama Kendaraan Bermotor Tahun 2006. 
5. Peraturan Gubernur yang mengatur tentang PKB sebagai aturan pelaksanaan peraturan daerah tentang PKB pada provinsi yang dimaksud.

\section{Objek dan Pajak Kendaraan Bermotor}

Objek Pajak Kendaraan Bermotor adalah kepemilikan atau penguasaa kendaraan bermotor yang digunakan di semua jenis jalan darat seperti kawasan : Bandara, Pelabuhan laut, Perkebunan, Kehutanan, Pertanian, Pertambangan, Industri, Perdagangan dan Sarana olah raga dan rekreasi.

Wajib Pajak adalah orang pribadi atau badan yang memiliki kendaraan bermotor, jika wajib pajak merupakan badan maka kewajiban perpajakannya diwakili oleh pengurus atau kuasa hukum badan tersebut.

\section{Tata Cara Pembayaran dan Penagihan PKB}

PKB terutang harus dilunasi/dibayar sekaligus dimuka untuk masa dua belas bulan. PKB dilunasi selambat-lambatnya 30 hari sejak diterbitkan SKPD, SKPDKB, SKPDKBT, STPD, surat Keputusan Pembetulan, surat Keputusan Keberatan, dan Putusan Banding yang menyebabkan jumlah pajak yang harus dibayar bertambah. Pembayaran PKB dilakukan ke kas daerah bank, atau tempat laian yang ditunjuk oleh gubernur, dengan menggunakan surat setoran pajak daerah.

\section{Sistem Pemungutan Pajak}

Sistem pemungutan pajak di Indonesia baik Pajak Pusat maupun Pajak Daerah menganut beberapa sistem antara lain:
1. Official Assessment System
Official Assessment System adalah suatu sistem pemungutan pajak yang memberikan wewenang kepada pemerintah (fiskus) untuk menentukan besarnya pajak yang terutang oleh Wajib Pajak.

\section{Self Assessment System}
Self Assessment System adalah suatu sistem pemungutan pajak yang memberikan wewenang kepada Wajib Pajak untuk menentukan sendiri besarnya pajak yang terutang.
3. Witholding System
Witholding System adalah suatu sistem pemungutan pajak yang memberi wewenang kepada pihak ketiga (bukan Fiskus dan bukan Wajib Pajak ) untuk menentukan besarnya pajak yang terutang oleh Wajib Pajak.

\section{Pajak Daerah dan PAD}

Pajak Daerah merupakan iuran wajib yang dilakukan oleh orang pribadi atau badan kepada daerah tanpa imbalan langsung yang seimbang, yang dapat dipaksakan berdasarkan peraturan perundangundangan yang berlaku, yang digunakan untuk membiayai penyelenggaraan pemerintahan daerah dan pembangunan daerah.

Menurut Herlina Rahman, 2005 dalam Damang, 2011 Pendapatan Asli Daerah merupakan pendapatan daerah yang bersumber dari hasil pajak daerah ,hasil distribusi hasil pengelolaan kekayaan daerah yang dipisahkan dan lain-lain pendapatan asli daerah yang sah dalam menggali pendanaan dalam pelaksanaan otda sebagai perwujudan asas desentralisasi. Adapun sumber-sumber pendapatan asli daerah (PAD) sebagaimana datur dalam Undang-Undang Nomor 32 Tahun 2004 Pasal 157, yaitu:

1. Hasil Pajak Daerah

2. Hasil Retribusi Daerah

3. Hasil pengelolaan kekayaan daerah yang dipisahkan

4. Lain-lain pendapatan asli daerah yang sah. 


\section{Kerangka Pemikiran}

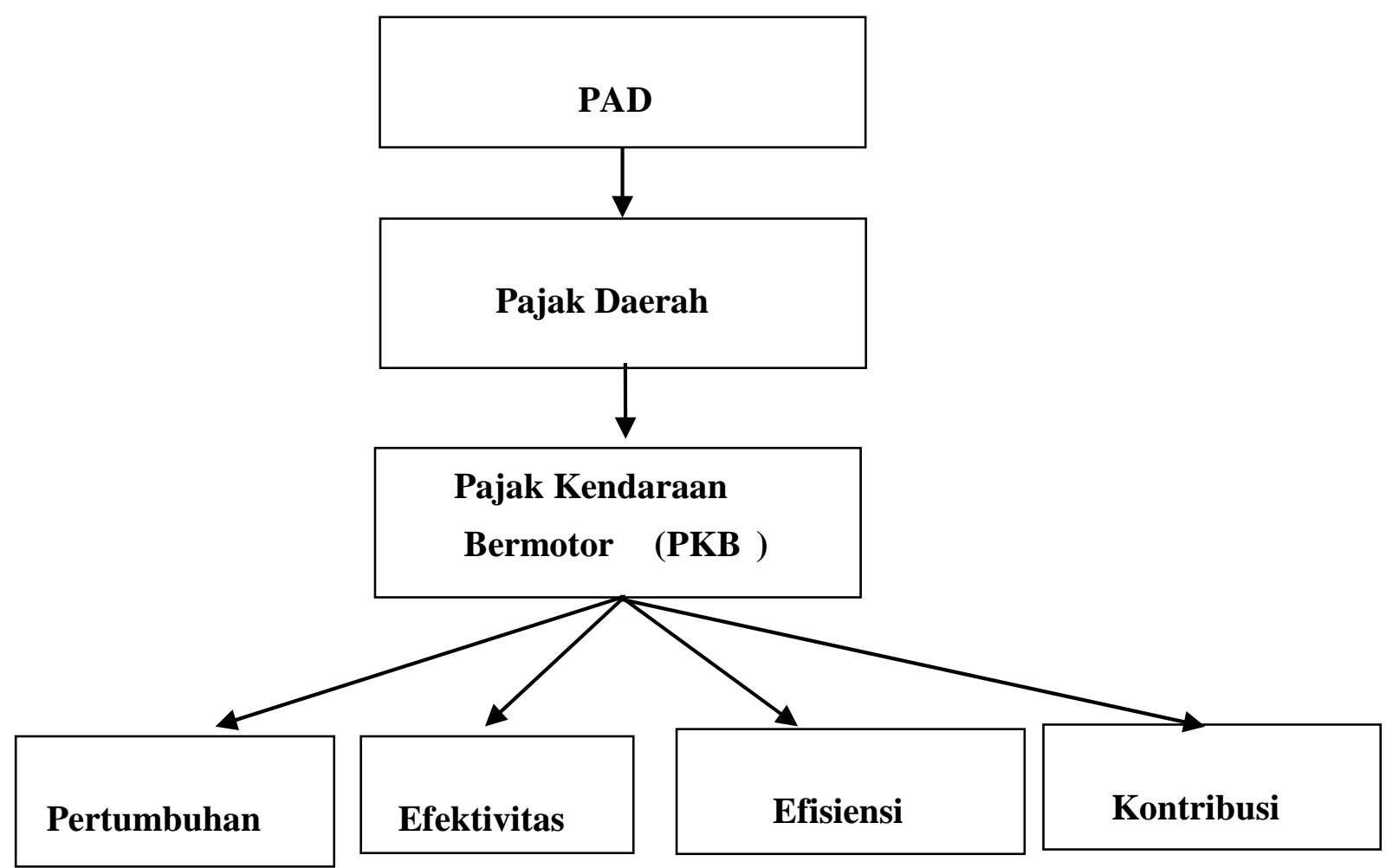

\section{Gambar 2 Kerangka Pemikiran}

\section{METODE PENELITIAN}

Lokasi penelitian yang dimaksud dalam penelitian ini adalah di Kantor Dinas Pendapatan Daerah Kota Palu. Ada dua jenis data yang digunakan dalam penelitian ini, yaitu data kuantitatif dan data kualitatif. Sumber data dalam penelitian ini membutuhkan data-data yang relevan untuk bisa memformulasikan masalah dan menyelesaikan permasalah yang diteliti. Sumber data dalam hal ini mencakup data primer dan data sekunder.

Hasil pemungutan Pajak Kendaraan Bermotor (PKB) adalah pajak atas kepemilikan dan/atau penguasaan kendaran bermotor dalam variabel independennya merupakan keseluruhan hasil pajak daerah. Variabel yang digunakan dalam penelitian adalah sebagai berikut:

1. Kontribusi merupakan realisasi pajak kendaraan bermotor dibandingkan dengan realisasi pajak daerah kota Palu.

2. Berdasarkan undang-undang nomor 34 tahun 2000 yang diperkuat dengan peraturan pemerintah nomor 28 tahun 2005 tentang pajak daerah dikatakan bahwa pajak kendaraan bermotor (PKB) adalah pajak yang dipungut atas kepemilikan dan atau penguasaan kendaran bermotor

3. Pajak daerah merupakan pungutan yang merupakan hak prerogatif pemerintah.

4. Target penerimaan pajak kendaraan bermotor (PKB) merupakan suatu target yang diharapkan dapat tercapai dalam pelaksaan pambayaran pajak kendaraan bermotor, atas suatu rencana, anggaran yang ingin dicapai atas suatu pajak kendaraan bermotor di kota Palu yang terdiri dari sedan/station, jeep, mini bus, bus, microbus, pick up, truk, dan sepeda motor dalam satuan rupiah.

5. Realisasi pajak kendaraan bermotor (PKB) merupakan jumlah penerimaan pajak kendaraan bermotor secara keseluruhan yang diterima dari jenis kendaraan bermotor yang ada di kota Palu yang terdiri dari sedan/station, jeep, mini bus, bus mikrobus, pick up, truk dan sepeda motor dalam satuan rupiah. 
Teknik pengambilan data dilakukan dengan data rasional yang benar adanya di lapangan dan kemudian bentuk data berupa data nominal adalah data yang berbentuk angka yang dapat diperhitungkan. Menurut Sugiyono, (1997:70) metode ini dilakukan dengan mencatat atau mengumpulakan data-data target penerimaan pajak kendaraan bermotor (PKB), realisasi pajak kendaraan bermotor (PKB), nilai jual kendaran bermotor (NJKB) yang diperoleh dari kantor Dinas Pendapatan Daerah kota Palu tahun 2011-2015.

Teknik analisis data yang digunakan dalam penelitian menggunakan analisis deskriptif ditujukan untuk mengetahui gambaran target penerimaan Pajak Kendaraan Bermotor (PKB), realisasi Pajak Kendaraan Bermotor (PKB). Nilai jual kendaraan bermotor (NJKB) di Kantor Dinas Pendapatan Daerah Provinsi Sulawesi Tengah khususnya di kota Palu.

\section{Analisis Pertumbuhan}

Mengetahui perilaku kontribusi PKB, hasil analisis presentasi kontribusi PKB akan digrafikkan berdasarkan tahun analisis (2011-2015). Nilai pertumbuhan PAD dan PKB akan dihitung dengan menggunakan formula berikut:

$$
\text { Pertumbuhan } P K B=\frac{P K B(t)-P K B(t-1)}{P K B t-1} \times 100 \%
$$

Keterangan: $\quad$ PKB = Pajak Kendaraan Bermotor

(t) $\quad=$ Tahun Berjalan

$(\mathrm{t}-1) \quad=$ Tahun Sebelumnya

di mana $t$ adalah tahun berjalan.

\section{Analisis Efektifitas}

Besarnya efektifitas pajak dapat dihitung dengan rumus sebagai berikut (Halim, 2004:93) :

$$
\text { Efektifitas = Realisasi Pendapatan PKB X100\% }
$$

Target Pendapatan PKB

Menghitung pencapaian kinerja efektifitas yaitu dengan membandingkan antara output realisasi dengan output yang direncanakan, dengan kategori tingkat efektifitas yang dicapai dapat dilihat pada tabel sebagai berikut:

Tabel 2 Kriteria Persentase Efektivitas

\begin{tabular}{|l|l|}
\hline Persentase Kinerja & Kriteria \\
\hline$>100 \%$ & Sangat Efektif \\
\hline $90 \%-100 \%$ & Efektif \\
\hline $80 \%-90 \%$ & Cukup Efektif \\
\hline $60 \%-80 \%$ & Tidak Efektif \\
\hline$<60 \%$ & Sangat Tidak efektif \\
\hline
\end{tabular}

Sumber : (Halim, 2004:93 dalam jurnal Adi Putra Tenggara)

\section{Analisis Efisiensi}

Pendekatan ini dimaksudkan untuk mengukur bagian dari pajak yang digunakan untuk menutupi biaya pemungutan, termaksud biaya-biaya operasional (Halim, 2004:93)

$$
\text { Efisiensi }=\text { BiayaPemungutan } \mathrm{PKB} X 100 \%
$$

$$
\text { Realisasi PendapatanPKB }
$$


Putra A.

\section{Analisis Kontribusi}

Kontribusi pajak kendaraan bermotor terhadap pajak daerah dapat dihitung dengan formulasi:

$$
\text { Kontribusi }=\frac{\text { Realisasi Penerimaan } P K B}{\text { Target Penerimaan } P K B} \times 100 \%
$$

Skala pengukuran kontribusi Pajak Kendaraan Bermotor (PKB) didasarkan pada kriteria yang disusun dalam tabel berikut:

Tabel 3 Kriteria Persentase Kontribusi

\begin{tabular}{|l|l|}
\hline Presentase Kontribusi & Kriteria \\
\hline$<10 \%$ & Sangat Kurang \\
\hline $10 \%-20 \%$ & Kurang \\
\hline $20 \%-30 \%$ & Sedang \\
\hline $30 \%-40$ & Cukup Baik \\
\hline $40 \%-50 \%$ & Baik \\
\hline$>50 \%$ & Sangat Baik \\
\hline
\end{tabular}

Sumber : (Halim, 2004:163 dalam jurnal Adi Putra Tenggara)

\section{HASIL DAN PEMBAHASAN}

\section{Hasil Penelitian}

\section{Hasil Kendaraan Pajak Bermotor}

Mengetahui perilaku kontribusi PKB, hasil analisis presentasi kontribusi PKB akan digrafikkan berdasarkan tahun analisis (2011-2015). Demikian juga jumlah kendaraan bermotor akan digrafikkan terhadap tahun periode yang sama. Perilaku pertumbuhan PAD juga akan dianalisis untuk melihat kaitannya dengan pertumbuhan PKB selama periode tahun 2011-2015. Laju pertumbuhan pajak kendaraan bermotor di kota Palu dari tahun ketahun adalah sebagai berikut:

\section{Tabel 4}

Hasil Pertumbuhan Pajak Kendaraan Bermotor (PKB)

di Kota Palu Tahun 2011-2015

\begin{tabular}{|l|c|c|c|}
\hline \multicolumn{1}{|c|}{ Tahun } & Realisasi & Pertumbuhan & Keterangan \\
\hline 2011 & 55.695 .994 .014 & - & \multirow{2}{*}{$\begin{array}{c}\text { Secara riil terlihat } \\
\text { meningkat namun }\end{array}$} \\
\cline { 1 - 2 } secara persentase \\
pertumbuhannya \\
berfluktuasi
\end{tabular}

Sumber : Data diolah (Oktober 2016) 


\section{Hasil Efektifitas Penerimaan Pajak Kendaraan Bermotor}

Tabel 5

Hasil Efektifitas Pajak Kendaraan Bermotor (PKB) di Kota Palu Tahun 2011-2015

\begin{tabular}{|c|c|c|c|c|}
\hline Tahun & $\begin{array}{c}\text { Realisasi Pendapatan } \\
\text { PKB (Rp) }\end{array}$ & $\begin{array}{c}\text { Target } \\
\text { Pendapatan (Rp) }\end{array}$ & Efektifitas & Keterangan \\
\hline 2011 & 56.693 .357 .014 & 51.183 .229 .363 & $110,76 \%$ & Sangat Efektif \\
\hline 2012 & 66.018 .527 .884 & 50.858 .075 .200 & $129,80 \%$ & Sangat Efektif \\
\hline 2013 & 75.218 .260 .771 & 72.773 .140 .100 & $103,35 \%$ & Sangat Efektif \\
\hline 2014 & 85.126 .531 .845 & 77.322 .652 .600 & $110,09 \%$ & Sangat Efektif \\
\hline 2015 & 91.595 .969 .985 & 99.675 .677 .272 & $91,89 \%$ & Efektif \\
\hline Rata-rata & & $109,17 \%$ & Sangat Efektif \\
\hline
\end{tabular}

Sumber : Data diolah (Oktober 2016)

Hasil Efisiensi Pajak Kendaraan Bermotor

Tabel 6

Efisiensi Pajak Kendaraan Bermotor (PKB) di Kota Palu Tahun 2011-2015

\begin{tabular}{|c|c|c|c|c|}
\hline Tahun & Realisasi & Biaya Pemungutan & Efisiensi & Keterangan \\
\hline 2011 & $55.695 .994 .014,00$ & $2.784 .799 .700,7$ & 0,05 & Efisien \\
\hline 2012 & $66.004 .226 .184,00$ & 3.300 .211 .309 & 0,05 & Efisien \\
\hline 2013 & $75.218 .260 .771,00$ & 3.760 .913 .039 & 0,05 & Efisien \\
\hline 2014 & $78.231 .497 .488,00$ & 3.911 .574 .874 & 0,05 & Efisien \\
\hline 2015 & $91.595 .969 .893,00$ & 4.579 .798 .495 & 0,05 & Efisien \\
\hline Rata-rata & 0,05 & Efisien \\
\hline
\end{tabular}

Sumber : Data diolah (Oktober 2016)

Hasil Kontribusi Pajak Kendaraan Bermotor

Tabel 7

Hasil Kontribusi Pajak Kendaraan Bermotor (PKB) di Kota Palu Tahun 2011-2015

\begin{tabular}{|c|c|c|c|}
\hline Tahun & Target & Realisasi & Kontribusi \\
\hline 2011 & 50.143 .345 .733 & 55.695 .994 .014 & $111.07 \%$ \\
\hline 2012 & 66.004 .226 .184 & 64.846 .430 .500 & $98.24 \%$ \\
\hline 2013 & 69.668 .943 .500 & 75.218 .260 .771 & $107.96 \%$ \\
\hline 2014 & 79.575 .801 .500 & 78.231 .497 .488 & $98.31 \%$ \\
\hline 2015 & 99.675 .677 .272 & 91.595 .969 .893 & $91.89 \%$ \\
\hline Rata-rata & & $101,49 \%$ \\
\hline
\end{tabular}

Sumber : Data diolah ( Oktober 2016)

\section{Pembahasan Hasil Penelitian}

\section{Deskripsi Pertumbuhan Pajak Kendaraan Bermotor}

Berdasarkan tabel hasil pertumbuhan, menggambarkan bahwa tingkat pertumbuhan pendapatan Pajak Kendaraan Bermotor (PKB) selama 5 tahun, dimana setiap tahunnya angka rata-rata pertumbuhan sebesar 13,39 \%. Pada tahun 2011, pendapatan Pajak Kendaraan Bermotor (PKB) sebesar Rp. 55.695.994.014,00 meningkat menjadi Rp. 64.846.430.500,00 atau tumbuh $16,42 \%$ di tahun 2012. Pada tahun 2013 pendapatan pajak kendaraan bermotor meningkat sebesar Rp. 75.218.260.771,00 tetapi dengan tingkat pertumbuhan lebih kecil 16,00\% pada tahun 2014 pajak 
kendaraan bermotor sebesar Rp. 78.231.497.488,00, dengan pertumbuhan 4,06\%. ini terjadi karena kurang kesadaran dari masyarakat untuk membayar pajak kendaraan bermotornya. Sedangkan Tahun 2015 mengalami peningkatan mencapai 17,08\% karena kesadaran masyarakat mulai tumbuh untuk membayar pajak. Berdasarkan hasil wawancara peneliti kepada Ibu Dra. Jintan Lembah selaku Kepala Seksi Penetapan dan Penerapan Pajak menyatakan, "Hal ini didukung oleh kebijakan pemerintah daerah Provinsi Sulawesi Tengah dengan adanya penghapusan denda pajak sebesar 3 tahun dari masa kendaraan tersebut dikenakan denda". Rata-rata laju pertumbuhan pajak kendaraan bermotor di Kota Palu adalah $13.39 \%$ per tahun dikatakan tidak berhasil, dikarenakan Dinas Pendapatan Daerah Kota Palu untuk dapat meningkatkan penerimaan Pajak Kendaraan Bermotor dengan lebih cermat dalam melakukan pendataan potensi pajak kendaraan bermotor pada tahun berikutnya.

Pajak kendaraan bermotor meningkat tetapi tingkat pertumbuhan Pendapatan Asli Daerah khususnya di bidang Pajak Kendaraan Bermotor (PKB) berfluktuatif disebabkan oleh realisasi pajak kendaraan bermotor yang meningkat setiap tahunnya. Artinya peningkatan realisasi pajak kendaraan bermotor cenderung menurun. Jika dilihat kembali, maka presentase laju pertumbuhan pajak kendaraan bermotor kota Palu dari tahun 2011 sampai dengan 2015 mengalami fluktuatif.

\section{Deskripsi Efektifitas Penerimaan Pajak Kendaraan Bermotor}

Untuk mengukur tingkat efektifitas dapat memberikan peringkat dengan menggunakan metode skala peringkat (Halim, 2004:93). Adapun skala peringkat yang dimaksud yaitu skala antara $>100 \%$ dikategorikan sangat efektif, 90-100 dikategorikan efektif, 80-90 dikategorikan cukup efektif, 60-80 dikategorikan kurang efekfif dan $<60 \%$ dikategorikan tidak efektif.

Berdasarkan tabel hasil efektifitas, pendapatan pajak kendaraan bermotor setiap tahunnya mengalami peningkatan secara terus menerus. Tetapi jika dicermati dengan pencapaian tingkat efektifitas, dimana tahun 2011 realisasi yang diterima melebihi dari target yang telah ditentukan dengan persentase $110,76 \%$ dikategorikan sangat efektif. Dapat dilihat bahwa pada target pendapatan pajak kendaraan bermotor sebesar 51.183.229.363 sedangkan realisasi pendapatan pajak kendaraan bermotor sebesar 56.693.357.014 artinya perbandingan antara target dan realisasi sesuai dengan harapan yang diinginkan oleh UPTD Kota Palu.

Tahun 2012, realisasi yang diterima sama seperti pada tahun sebelumnya yang melebihi dari target yang sudah ditentukan dengan persentase $129,80 \%$, dikategorikan sangat efektif. Dapat dilihat bahwa pada target pendapatan pajak kendaraan bermotor sebesar 50.858.075.200 sedangkan realisasi pendapatan pajak kendaraan bermotor sebesar 66.018.527.884 artinya perbandingan antara target dan realisasi sesuai dengan harapan yang diinginkan oleh UPTD Kota Palu. Hal ini disebabkan karena pemerintah gencar melakukan sosialisasi mengenai pentingnya pembayaran pajak kendaraan bermotor sehingga memudahkan masyarakat dalam melakukan pembayaran pajak.

Tahun 2013, realisasi yang diterima melebihi target yang sudah ditentukan dengan persentase $103,35 \%$, dikategorikan sangat efektif meskipun pada tahun ini tingkat efektifitas masih sangat efektif namun, bila dibandingkan tahun sebelumnya pada tahun 2013 terjadi penurunan tingkat efektifitas. Dapat dilihat bahwa pada target pendapatan pajak kendaraan bermotor sebesar 72.773.140.100 sedangkan realisasi pendapatan pajak kendaraan bermotor sebesar 75.218.260.771 artinya perbandingan antara target dan realisasi sesuai dengan harapan yang diinginkan oleh UPTD Kota Palu. Hal ini dikarenakan tingkat perbandingan realisasi lebih besar dibandingkan dengan target pendapatan pajak kendaraan bermotor Kota Palu.

Pada tahun 2014 menunjukkan hasil yang sangat baik, yaitu realisasi yang diterima melebihi dari target yang sudah ditentukan dengan angka persentase yang dicapai adalah 110,09\%. Dapat dilihat bahwa realisasi PKB sebesar 85.126.531.845 sedangkan pada target yang ditentukan hanya sebesar 77.322.652.600. Hal ini dapat dikategorikan sangat efektif. 
Pada tahun 2015 realisasi yang diterima termasuk dikategori efektif karena hanya mencapai $91,89 \%$, penurunan realisasi yang tejadi di tahun tersebut akibat masyarakat yang kurang menanggapi betapa pentingnya membayar pajak kendaraan bermotor yang masih terdaftar dan masih terkena pajak. Hal ini menunjukkan bahwa masyarakat tidak mengerti tentang adanya pajak kendaraan bermotor sebenarnya untuk meningkatkan pembangunan daerah, khususnya di Kota Palu. Realisasi yang terjadi pada tahun 2015 sebesar 91.595.969.985 sedangkan target yang ingin dicapai sebesar 99.675.677.272 sehingga dikategorikan efektif karena termasuk pada kriteria persentase antara 80 - 100\%.

Secara rata-rata, tingkat efektifitas pajak kendaraan bermotor adalah 109,17\% dengan kategori sangat efektif. Artinya bahwa kinerja pemerintah daerah dalam mengelola pemungutan pajak kendaraan bermotor selama 5 tahun sudah sangat efektif. Hal ini juga didukung dari hasil wawancara bersama Ibu Dra. Jintan Lembah selaku Kepala Seksi Penetapan dan Penerapan Pajak menyatakan "proses pengendalian dan pengawasan yang baik terhadap pemungutan pajak kendaraan bermotor di Kota Palu sudah sangat baik".

\section{Deskripsi Efisiensi Pajak Kendaraan Bermotor}

Mengukur efisiensi pajak kendaraan bermotor hasil yang dapat yaitu kurang dari 1 atau 100\% (<1 atau 100\%) dikatakan efisien dan jika hasil yang dicapai lebih dari 1 atau 100\% (> 1 atau 100\%) dikatakan tidak efisien.

Berdasarkan Tabel efisiensi, menunjukkan realisasi pendapatan pajak kendaraan bermotor meningkat setiap tahunnya diikuti dengan meningkatnya biaya pungut yang dikeluarkan dalam pemungutan pajak. Perbandingan setiap tahunnya oleh realisasi pajak kendaraan bermotor dan biaya pungut menunjukkan nilai 0,05 atau 5\%. Jika disesuaikan dengan kategori efisiensi, maka pajak kendaraan bermotor dikatakan efisien. Hal ini disebabkan oleh besarnya biaya pungut yang ditetapkan hanya sebesar $5 \%$.

Pada tahun 2011 realisasi pajak kendaraan bemotor berjumlah 55.695.994.014.00 dibagi dengan biaya pemungutannya yang diambil dari realisasi sebesar 5\% maka didapatkan hasil senilai 2.784.779.700,7. Pada tahun 2012 realisasi pajak kendaraan bemotor berjumlah 66.004.226.184,00 dibagi dengan biaya pemungutannya yang diambil dari realisasi sebesar 5\% maka didapatkan hasil senilai 3.300.211.309.

Pada tahun 2013 realisasi pajak kendaraan bemotor berjumlah 75.218.260.771,00 dibagi dengan biaya pemungutannya yang diambil dari realisasi sebesar 5\% maka didapatkan hasil senilai 3.760.913.039. Pada tahun 2014 realisasi pajak kendaraan bemotor berjumlah 78.231.497.488,00 dibagi dengan biaya pemungutannya yang diambil dari realisasi sebesar 5\% maka didapatkan hasil senilai 3.911.574.874.

Pada tahun 2015 realisasi pajak kendaraan bemotor berjumlah 91.595.969.893,00 dibagi dengan biaya pemungutannya yang diambil dari realisasi sebesar 5\% maka didapatkan hasil senilai 4.579.798.495. Oleh karena itu, besarnya realisasi yang diterima atau kecilnya realisasi yang diterima tidak akan berpengaruh pada tingkat efisiensi pajak kendaraan bermotor. Artinya besar kecilnya realisasi pasti akan tetap efisien.

Tingkat efisiensi penerimaan pajak kendaraan bermotor di Kota Palu dalam lima tahun terakhir dapat dikatakan meningkat dengan sangat baik. Secara keseluruhan efisiensi pajak kendaraan bermotor di Kota Palu dari tahun 2011, 2012, 2013, 2014, dan 2015 dapat dikategorikan efisien. Penelitian ini didukung oleh hasil wawancara bersama Ibu Dra. Jintan Lembah selaku Kepala Seksi Penetapan dan Penerapan Pajak menyatakan "ini implementasi efisiensi pajak kendaraan bermotor di Kota Palu yang telah di lakukan oleh pemerintah khususnya pihak UPTD Kota Palu mengalami perkembangan. Diharapkan bagi UPTD Kota Palu dapat mempertahankan dan terus meningkatkan pelaksanaan efisiensi pajak kendaraan bermotor untuk kemajuan pembangunan daerah". 


\section{Deskripsi Kontribusi Pajak Kendaraan Bermotor}

Mengukur kontribusi pajak kendaraan bermotor, skala pengukuran yang digunakan yaitu dari $<10 \%$ dikatakan kontribusi sangat kurang, 10\%-20\% dikatakan kurang, 20\%-30\% dikatakan sedang, 30\%$40 \%$ dikatakan cukup baik, 40\%-50\% dikatakan baik, dan diatas $>50 \%$ terkontribusi sangat baik.(Halim, 2004:163)

Berdasarkan tabel kontribusi, Secara keseluruhan rata-rata kontribusi Pajak Kendaraan Bermotor terhadap Pendapatan Asli Daerah dalam lima tahun terakhir adalah 101,49\% per tahun. Pada tahun 2011 tingkat kontribusi pajak kendaraan bermotor di Kota Palu sebesar 111,07\%, berdasarkan kriteria dari kontribusi persentase dapat dikatakan terkontribusi sangat baik karena tingkat persentasenya $>50 \%$. Adapun target kontribusi pada tahun 2011 sebesar 50.143.345.733 sedangkan realisasi kontribusinya sebesar 55.695.994.014.

Pada tahun 2012 terjadi penurunan sebesar 98,24\%, namun tingkat kontribusi dapat dicapai karena tingkat persentase $>50 \%$ sehingga dapat dikategorikan terkontribusi sangat baik. Hal ini dapat dilihat pada tahun 2012 target kontribusi sebesar 66.004.226.184 sedangkan realisasi kontribusinya sebesar 64.846.430.500.

Pada tahun 2013 tingkat kontribusi kembali mengalami peningkatan yaitu target kontribusinya sebesar 69.668.943.500 sedangkan pencapaian realisasinya sebesar 75.218.260.771 dengan persentasenya $107,96 \%$, dan dapat dikategorikan terkontribusi sangat baik dengan tingkat persentase kontribusi $>50 \%$.

Tahun 2014 tingkat kontribusi pajak kendaraan bermotor sebesar 98,31\%, dan dikategorikan terkontribusi sangat baik dengan persentase $>50 \%$. Hal ini dapat dilihat target kontribusi pajak kendaraan bermotor Kota Palu sebesar 79.575.801.500 sedangkan realisasinya sebesar 78.231.497.488.

Pada tahun 2015 tingkat kontribusi pajak kendaraan bermotor di Kota Palu sebesar 91,89\%. Berdasarkan tingkat persentase dapat dikategorikan sangat baik karena $>50 \%$. Hal ini dapat dilihat target kontribusi pajak kendaraan bermotor Kota Palu sebesar 99.675.677.272 sedangkan realisasinya sebesar 91.595.969.893. Angka tersebut menggambarkan bahwa pajak kendaraan bermotor sangat baik memberikan kontribusi terhadap Pendapatan Asli Daerah di Kota Palu.

Berdasarkan data di atas, maka disimpulkan bahwa tingkat kontribusi pajak kendaaan bermotor di kota Palu mengalami peningkatan yang sangat baik, sebab pada setiap tahunnya tingkat persentasenya $>50 \%$ yang sesuai dengan kriteria kontirbusi pajak kendaraan bermotor. Dengan demikian, kinerja pemerintah daerah Kota Palu dalam hal meningkatkan Pendapatan Asli Daerah yang secara khusus adalah kontribusi pajak kendaraan bermotor sudah sangat baik. Untuk itu, perlunya dipertahankan dan lebih ditingkatkan lagi, sehingga dapat mencapai tujuan pemerintah baik skala lokal hingga nasional pada peningkatan dan pengembangan terhadap kontribusi pajak kendaraan bermotor. Tentunya dengan pencapaian tersebut kebutuhan pemerintah dalam menunjang pembangunan daerah dapat terealisasi”. Ungkap Ibu Dra. Jintan Lembah selaku Kepala Seksi Penetapan dan Penerapan Pajak Dinas Pendapatan Daerah Kota Palu (DISPENDA).

\section{KESIMPULAN DAN SARAN}

\section{Kesimpulan}

Berdasarkan hasil penelitian dan analisis yang dilakukan mengenai laporan realisasi Pajak Kendaraan Bermotor (PKB) pada UPTD Kota Palu Provinsi Sulawesi Tengah Tahun 2011 sampai dengan 2015, dapat disimpulkan sebagai berikut :

1. Pertumbuhan penerimaan pajak kendaraan bermotor di UPTD Kota Palu tahun 2011 sampai dengan 2015 mengalami fluktuatif, pada tahun 2011 memberikan pertumbuhan sebesar 10,54\%, sementara pada tahun 2012 mengalami peningkatan sebesar 16,43\%, pada tahun 2013 sampai dengan tahun 2014 mengalami penurunan berturut-turut sebesar 16,00\%, dan 4,06\%, dan pada 
tahun 2015 pertumbuhan mengalami peningkatan kembali sebesar 17,08\%. Dengan demikian diperlukan kerja sama antara Pemerintah dan Masyarakat untuk semakin sadar dalam membayar pajak kendaraan bermotor dan pajak daerah yang merupakan kewajiban bagi setiap warga Negara Indonesia.

2. Efektifitas penerimaan pajak kendaraan bermotor di UPTD Kota Palu tahun 2011 sampai dengan 2015 mengalami fluktuatif, peningkatan tertinggi terjadi pada tahun 2012 sebesar 129,80\% sementara penurunan terendah pada tahun 2015 sebesar 91,89\%. Dengan demikian terlihat bahwa semakin meningkatnya kinerja pemerintah dalam pananganan pemungutan pajak kendaraan bermotor di Kota Palu.

3. Efisiensi penerimaan pajak kendaraan bermotor di UPTD Kota Palu tahun 2011 sampai dengan 2015 dikategorikan efisien. Pendapatan pajak kendaraan bermotor secara rata-rata dapat dikatakan efisien yaitu sebesar 0,05 atau $5 \%$. Hal ini disebabkan oleh biaya pungut yang ditetapkan sebesar $5 \%$ dari hasil realisasi. Jadi, besar atau kecilnya realisasi yang didapatkan pasti akan tetap efisien.

4. Kontribusi penerimaan pajak kendaraan bermotor di UPTD Kota Palu pada tahun 2011 sampai dengan 2015 mengalami fluktuatif. Terlihat dari tahun 2011 perkembangan kontribusi pajak kendaraan bermotor mencapai $111,07 \%$, tahun 2012 jumlah kontribusi mengalami penurunan mencapai 98,24\%, dan pada tahun 2013 jumlah kontribusi meningkat kembali sebesar 107,96\%, sedangkan pada tahun 2014 dan 2015 jumlah kontribusi menurun berturut-turut mencapai 98,31\% dan $91,89 \%$. Hal ini menunjukkan bahwa tingkat kontribusi penerimaan pajak kendaraan bermotor masih sangat mengalami fluktuatif sehingga diperlukan peran pemerintah yang lebih besar lagi dalam penanganan pajak di Kota Palu.

\section{Saran}

1. Kepada pemerintah pusat agar memberikan kewenangan kepada pemerintah daerah Provinsi Sulawesi Tengah yang lebih luas dalam menarik semua pajak di daerah sehingga dapat meningkatkan Pendapatan Asli Daerah, yang selanjutnya kepada pemerintah daerah Provinsi Sulawesi Tengah lebih memberi kewenangan pula terhadap Pemerintah Kabupaten/Kota untuk bekerja dan bertanggung jawab dalam bekerja sesuai tugas dan fungsinya mengurus pajak dari masyarakat.

2. Kepada unit pelaksana teknis daerah (UPTD) di Kota Palu Provinsi Sulawesi Tengah agar memaksimalkan penarikan Pajak Kendaraan Bermotor (PKB) dan Pajak Daerah dengan jalan melakukan sosialisasi tentang manfaat pembayaran pajak kepada masyarakat, sehingga hasil pembayaran pajak lebih optimal dalam merealisasikan pembangunan.

\section{REFERENSI}

Algifari, Guritno Mangkoesoebroto (1998). Teori Ekonomi Makro. Yokyakarta : STIE YKPN. Halim, Abdul (2004). Manajemen Keuangan Daerah, Edisi Revisi. AMP YKPN. Yogyakarta. Halim, Abdul dan Theresia Damayanti (2007). Pengelolaan Keuangan Daerah. Cetakan Pertama.

Sekolah Tinggi Ilmu Manajemen YKPN. Yogyakarta.

Ilyas, B, Wirawan dan Burton Richard. (2001). Hukum Pajak Edisi Pertama. Jakarta : Salemba Empat. Peraturan Daerah Provinsi Sulawesi Tengah Nomor 1 Tahun 2011. Tentang Pajak Daerah.

Peraturan Pemerintah Nomor 65 Tahun 2001. Tentang Pajak Daerah.

Sugiyono (1997). Statistika Untuk Penelitian. Bandung : CV Alfabeta.

Undang-Undang Republik Indonesia Nomor 32 Tahun 2004, Revisi dari Undang-Undang Nomor 22 Tahun 1999.

Undang-Undang Republik Indonesia Nomor 34 Tahun 2000, Revisi dari Undang-Undang Nomor 18 Tahun 1997. 


\section{Putra A.}

Undang-Undang Republik Indonesia Nomor 28 Tahun 2009, Revisi dari Undang-Undang Nomor 34 Tahun 2000. Tentang Pajak Daerah dan Retribusi Daerah.

Sumber lain: http://catatansmaku.blogspot.com/2011/08/pengelompokan-

pajak.html http://www.negarahukum.com/hukum/pendapatan-asli-

daerah.htmldamang2011 